\title{
NOTES ON PROSOBRANCHIATA.
}

\section{No. iv.-The Ontogenetic Stages Represented by the Gastropod Protoconch.}

\section{By H. Leighton Kesteven.}

i.-Introduction.

ii.-The Ontogenetic Stages.

iii.-The Naticoid Initial Whorl.

iv. - The Systematic Valde of the Protoconch.

\section{i.-Introduction.}

Since the publication of my paper on the "Protoconchs of certain Port Jackson Gastropoda" (2) in May, 1902, I have continued to devote a good deal of time to the study of these interesting " monuments" of early Gastropod development; some of the conclusions and results arrived at have appeared from time to time in these Proceedings and in the publications of the Australian Museum. The published results, however, stand for but a small portion of the study that has been devoted to the subject. In the execution of my duties while a member of the staff of the Australian Museum, many thousands of specimens passed through my hands for mounting and bestowal in their places in the cabinets and cases; all these were carefully examined as to their protoconchs, as was also no small portion of the large collection already bestowed and arranged before my appointment. Added to this, I have zealously collected material for the study, personally in New South Wales and Queensland, and by exchange from Victoria, South Australia and Tasmania. Here I should like to acknowledge my indebtedness to Mr. W. T. Bednall, of Adelaide, whose many consignments of rich shell 
sand have provided me with much useful material. Several genera have been studied as extensively as was Lotorium (3), but as there was no such immediate call for descriptions and figures of their protoconchs as there was in that case, I have not thought it desirable to publish the results.

When No. iii. of the present series(4) was written, I had been led to the conclusion that in some instances, e.g., Cymatium,* the so-called protoconch was really a secondary shell, and there suggested the term "pseudoprotoconch" for such. A more recent study of the protoconch of Megalatractus aruanus Linn.(5) has convinced me that a protoconch may be composed of portions formed during one or all of four important stages of early growth. An ideal protoconch would, in my conception, be composed of(1) the plug of the primitive shell-gland, (2) a portion formed by the veliger, (3) a portion formed during the nepionic stage, and finally (4) a portion formed during early neanic stages. I am therefore now inclined to withdraw the term pseudoprotoconch and replace it with the more explicit terms nepioconch and ananeanoconch proposed below.

Before proceeding to the purpose of the present paper, namely, a definition of and nomenclature for the above four conchyliaceous developmental records, I would justify my retention of and incidentally define the term "protoconch," which the conclusions herein set forth would seem to show to be a redundant misnomer. The term has been in the past, and is here, used to designate those few apical whorls which differ markedly either in contour or sculpture, or both, from the succeeding structure, which latter I have, for want of a better term, designated "adult structure." In the above sense the term "protoconch" is certainly useful, and even were I to advocate that it be no longer used, and were to coin, or make use of, some more explicit term, I am unable to flatter myself that my advice would be generally followed, a dual

* The name Cymatium is here used instead of Lotorium (the erstwhile Triton) in deference to the opinion of a growing majority that Bolton's names are admissible as nomenclatural entities. 
nomenclature would result. In fact, such a proceeding would be an unwarranted piece of pedantry; some such term is necessary, therefore that which already has a currency should be used, and at its current value. Grabau(1) has suggested that "protorteconch" would be more explicit than the term under consideration; in comparing the bulbous protoconch with the twisted protorteconch, the term will doubtless prove useful, but except in such cases its use is rather to be deprecated; it is in this way, apparently, that its author would use it.

\section{ii.-The Ontogenetic Stages.}

The names which I would give to the four component parts of the ideal protoconch are-Phyloconch, Veloconch, Nepioconch and Ananeanoconch, and their definitions as follow :-

1. Phyloconch.-This is the "primitive" shell of Lankester.(6) It is formed by almost every member of the phylum, but, with rare exceptions, it is shed at an early age and does not enter into the composition of the protoconch.

2. Veloconch.-The greater portion of this is formed during the veliger stage, though it may have been begun just before that stage.

3. Nepioconch. - This is formed during the nepionic stage, but, for reasons given in a preceding paper,(4) I am inclined to regard it as of rare occurrence.

4. Ananeanoconch.-Formed during early neanic stages.

The phyloconch is, as already stated, the "primitive shell" of Lankester, and has been noted in every Gastropod of which the development has been studied. Sometimes it takes the form of a chitinous plug filling the first shell-gland. The phyloconch is very generally shed, but when retained it may be detected in the very young protoconch; instances of this are Clausilia, Neritina, and Paludina. In these, however, it is so minute that, had not the development of the molluses been studied, it is doubtful whether its presence in the protoconch would have been detected; in view of this fact, it appears likely that only by the method 
which led to its discovery in the above instances will its presence or absence be demonstrated in any protoconch.

The veloconch is of very general occurrence throughout the Gastropoda, occurring even in many of the molluses which in later life are without any trace of shell (Eolis, etc.). It may be succeeded by either nepioconch (Murex denudata Pẹrry) or ananeanoconch (Cymatium), may be distinctly marked off from the succeeding portion (Murex, Dolium, Cassis, Capulus, etc.), or may be undefinable as to its ultimate limit (Triphora, some Cymatia and Systra), may be retained throughout life, or lost by abrasion and corrosion (Triphora, Megalatractus) or shed, by testaceous as well as naked molluses, at an early age (Cymatium). Finally, it may be either of the same substance as the adult cuticle or periostracum (Cymatium) or it may be calcareous (Murex, Triphora).

The nepioconch is perhaps existent only as the varix which divides the protoconch from the succeeding adult structure, as. typified in some Murices and Fusi; it may also be represented by some of the smooth protoconchs which have been moulded inside a horny veloconch, which was later shed. In a previous paper, however, wherein I have discussed the nepionic stage at some length, I showed that such casts are sometimes ananeanic structures (4 vide also 3 ).

The ananeanoconch, whilst present in all shells, unless lost by abrasion or corrosion, may be a component part of the protoconch, but may, as in Murex and some other genera, be a portion of the true conch. The name, it must be remembered, designates, not some particular portion of a shell, but any portion formed during a particular stage of development; thus may it be either protoconch or true conch. The ananeanoconch of Cymatium is formed after the pelagic larva has come to rest, and has lost the velum; it is in this instance moulded inside the horny veloconch, which is later shed; there is no nepioconch. In Melo and Megalatractus it was formed in the egg-capsule and was deposited inside a horny covering, but this latter is perhaps more nearly analogous to the adult periostracum than to the veloconch of 
Cymatium, and probably grew, pari passu, with the calcareous ananeanoconch, exactly as does the adult periostracum and shell; moreover, in Megalatractus the horny covering is extremely thin.

All the last three stages may be shown to be present or absent by the study of one or two growth-stages of the shell, and by taking into consideration the size and sculpture of the protoconch. Taking Megalatractus aruanus Linn., as being a good example wherewithal to illustrate the deductive methods which may be brought to bear on the subject.* From the large size of the mollusc when it escapes from the egg-capsule, we may deduce the fact that the velum had been aborted some time prior to that date; from the fact that the whorls are angled and nodulose, and

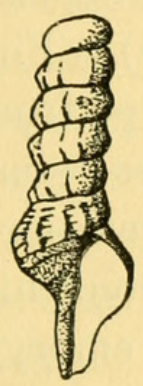

Fig. 1.

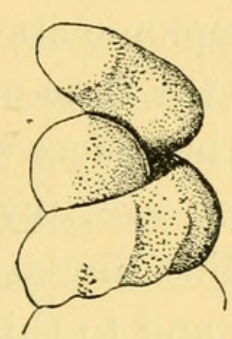

Fig. 2.

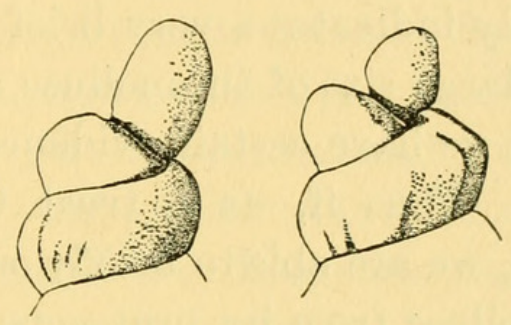

Fig. 1.-Protoconch (nat. size). Fig. 2.-Apical whorls of decollated protoconch showing the variation in the direction of its long axis and apparently in size, of the portion lost.

that some are striate, we deduce a mantle assuming the adult condition, and therefore well developed; this we may the more safely do from the fact that there is no demarcation between the later whorls of the protoconch and the earlier whorls of the conch, in short no signs of nepionic interruption. Again, there is a smooth thimble-shaped nuclear portion very distinctly marked off from the coiled whorls. The conclusions that may be arrived at from these deductions are that the smooth nuclear portion is

* A full description of the protoconch is given in my report on the "Anatomy of Megalatractus aruanus Linn." (5). For the opportunity of reproducing the figures, I have to thank the Trustees of the Australian Museum, who kindly granted the loan of the text-blocks. 
not older than the veloconch, that the nepioconch was very probably not formed, and that the whole of the coiled portion is ananeanoconch. If the nepioconch is present, it is represented by the earliest of the coiled whorls.

From the large size and very slight excentricity of the extreme apex (which consists of phyloconch (?) and veloconch) it may be inferred that the trochosphere was large, since excentricity of growth commences very shortly after that stage, and the symmetrical portion was probably moulded on the late trochosphere or early veliger, and the early veliger could hardly have been large had not the preceding stage been correspondingly large. From the absence of a nepioconch I deduce a poor development of the velum, because the absence of nepioconch probably indicates a very brief nepionic stage (vide 4). Finally, in the large size of the mollusc at the time of its escape from the capsule we have certain evidence that there was no free-swimming stage. Thus if, as I trust they are, my interpretations be correct, we are able to briefly outline the later embryonic history of a molluse from its protoconch, and to this extent embryology is placed within the range of palæomalacology.

The section may be fittingly concluded by the following quotation from Lankester-" . . . . we may speak of primary, secondary, and tertiary shells in Mollusca, recognising the fact that they may be merely phases fused by continuity of growth so as to form but one shell, or that, in other cases, they may be presented to us as separate individual things, in virtue of the non-development of the later phases, or in virtue of sudden changes in the activity of the mantle-surface causing the shedding or disappearance of one phase of shell-formation before a later one is entered upon."(6)

\section{iii.-The Naticoid Initial Whorl.}

In the paper above referred to(1) Grabau concludes that, because the initial whorl of many Gastropods was smooth, rounded and umbilicate, the Gastropod radicle was of this "naticoid" charaeter. The conclusion is very tempting, but it 
seems that if we look below the surface we shall find that it is one which will not stand the light of investigation. Although he does not explicitly state so, it is to be concluded that Grabau regarded the character as inherited; for I take it that it could have phylogenetic significance only as an inherited character. Reviewing the two characters, rotundity and umbilication. Firstly, rotundity: at the age when the mollusc deposits the initial whorl it is little more than a viscous particle of protoplasm, differentiated into cells certainly, but very little firmer. Now it is inconceivable that this viscous particle could form an angulated shell; it is not endowed with pseudopodia or power to change its rounded form for an angulated one as are the Rhizopoda. This consideration must, it would seem, deprive the rounded form of the initial whorl of any phylogenetic significance. Secondly, having regard to the umbilication, a moment's thought will show that all torteconchs are more or less umbilicate, and must of a necessity be so. In some instances the umbilicus is filled up with callus, and when the former is small we designate the latter columella. This is not a juggling with words, but a statement of a fact. It is impossible to wind a tube spirally without having an umbilicus at first, when the said tube is round in crosssection. When the whorls are wound in the same plane and are increasing in size there will be a concavity on both sides, one of which is merely a wide, much flattened umbilical cavity. Were it possible to so wind a shell as to envelop the preceding whorls, then would the umbilicus be non-existent, but the initial portion is thimble-shaped and symmetrical, so that such a thing is a practical impossibility. Thus we see that even such genera as Cyprcea, Bulla, Volvula, etc.-types from which both columella and umbilicus are absent-must have had an umbilicus at an early stage of development, for the envelopment of the whorls did not begin till one or two whorls were formed. From this it will be seen that the "naticoid initial whorl" is not an inherited character so much as the result of the twisting; i.e., the twisting is the inherited character and the umbilicus a necessary result. The endeavour to determine a Gastropod radicle seems 
to be somewhat futile. Granted that the torteconch evolved from a planoconch (such as Patella) and that we had the complete series to study, then would we be unable to draw the line between planoconch and torteconch; or granted that the torsion was inherited directly from the molluscan ancestor and that we had the complete genealogical tree, then would we debate as to which was molluse and which ancestor.

\section{iv.-The Systematic Value of the Protoconch.}

This is a question that is coming into greater and greater prominence, and one worthy of our closest attention; kept within its proper limits, it bids fair to be a most valuable character in arriving at a natural classification of the minor groups of the Gastropoda. There seems, however, to be a growing inclination to overestimate its value.

If the protoconch is a veloconch, then must we not lose sight of the fact that it was formed by the mollusc at the age when it had only just assumed a definite Gastropod character, that is the mollusc was so young that it had not as yet assumed generic characters, therefore the protoconch can hardly be reasonably used as a generic character. The same applies to an ananeanoconch moulded inside a veloconch. An ananeanoconch such as that of Megalatractus, which was formed independently of the veloconch, will, however, betray generic characters, as would the mollusc itself in the same (ananeanic) stage.

I concur with Grabau's contention(1) "that the protoconchs of all species within a given genus should agree as to their essential characters, and that no species can be congeneric in which the protoconchs show a radical difference," (the italics are mine) but I maintain that it has never, and believe that it never will be shown that there is a really essential deep-seated difference between the protoconchs of mollusca generically allied as to their shells and anatomy, unless the said protoconchs be ananeanoeonchs.

The question hinges on what is to be considered an essential or radical difference. Let us review one or two instances. Sup- 
posing that we are presented with shells absolutely congeneric, as far as they themselves show, but having, the one an almost planorboid protoconch, the other an elevated conoidal protoconch, would we be justified in separating them generically? I would answer the question by instancing the conoidal Polinices conicus Lam., and the almost planorboid $P$. incei Phil., and still more striking Littorina neritoides Brown, and L. scabra Linn., and ask do we separate these generically for the same reason. Moreover, our hypothetical case is almost paralleled in the genus Cymatium by species which are undoubtedly congeneric in shell, radula, operculum and every point of anatomy. Thus we see that the plan of coiling is not of generic importance as opposed to adult characters. Again, it is sometimes found that the protoconchs of a single genus differ in that the later whorls of some are sculptured whilst the whole protoconch of others is smooth. The sculpture in such cases will be found to be merely the first indication of the adult ornamentation, and to be attributable merely to extreme tachygenetic tendencies of the species possessing it, rather than to be regarded as an essential difference. Lastly, in the one genus there sometimes occur symmetrical conoidal protoconchs, and others having a large nucleus placed excentrically, with the later whorls coiled regularly. All protoconchs at their inception are thimble-shaped, therefore, if the trochosphere larva is large, and therefore also the early veliger, then will the thimble-shaped portion of the veloconch be large in proportion, it follows that when the asymmetry begins to appear the resultant coiling will be more or less excentric at first, unless the diameter of the shell-mouth increases very rapidly, that is, unless the mollusc itself enlarges very rapidly. From this we see that a large nucleus, excentric or regular, results from a large trochosphere larva; that is to say, the size of the nucleus is governed by the size of the egg. It would therefore be just as wrong to regard it as a character of classificatory value as it would be to classify the Aves by the size of their eggs.

Really critical differences between two protoconchs would be(1) two absolutely different types of sculpture, which were not 
merely the first appearance of the adult sculpture, whether accompanied or not by differences of contour; (2) the presence in one and absence from the other of some such bizarre feature as the sinuation and claw-like processes of Purpura protoconchs; and (3) a completely different axis of coiling in the two, as between Triphora and Turbonilla. Such, however, will most probably be found to be correlated with differences, of equal or greater importance, in shell or anatomy.

The conclusions of this section are that the protoconch is to be used in conjunction with other features, and that only where the other features, anatomic or conchological, are negative or unknown is it to be used in deciding a systematic position or generic segregation. It will often be found useful as an indicator of deeper seated differential characters otherwise unsuspected.

Just as this goes to press the Journal de Conchyliologie for May, 1905, has come to hand; in this number is an abstract by G. D(ollfus) of a review by Dr. Boettger of a recent paper from the pen of Grabau; the original of this review is not available to me, but as the writer's conclusions are very pertinent to the present discussion, I give the following free translation of the abstract-Dr. Boettger is of opinion that no weighty conclusions can be based on 'Hétérostylie,' that is to say, on the difference in the course of growth of the spire of Gastropod shells; he recalls the fact that Sturany in the expedition of the 'Pola' found very different embryos for Murex tribulus, and for Fusus bifrons, according to the situation whence they were collected, and that they were always larger when he collected these species in great depths than when he collected them in coastal regions. It seems, indeed, that the embryos of a single species are able to undergo a kind of adaptation, and that this differential character, far from recalling an ancestral form, appears as an 'accommodation' entirely secondary. 


\section{BIBLIOGRAPHY.}

1. Grabad, A. W.- "Studies of Gastropoda." American Naturalist xxxvi., No.43, 1902, p.917 et seq.

2. Kesteven, H. Leighton. - "The Protoconchs of Certain Port Jackson Gastropods." Proc. Linn. Soc. N. S. Wales, xxvii. Pt. 4, 1902, p.606 et seq.

3.

“'Notes on Prosobranchiata. No.i. Lotorium.' Loc. cit. p.709 et seq.

4. - Notes on Prosobranchiata. No. iii. The Neanic Shell of Melo diadema Lamk., and the Definition of the Nepionic Stage in the Gastropod Mollusc." Loc. cit. xxviii. Pt.2, 1903, p.443 et seq.

5. "The Anatomy of Megalatractus." Austr. Mus. Mem. iv. Sci. Res. of the Trawling Exped. of H.M.C.S. 'Thetis.' Pt.8, 1904, p.419 et seq.

6. Lankester, E. Ray.-Ency. Brit. edit. 9, xvi. p.639 and p.662, 1885; Zool. Arts. p.125, 1891. 


\section{$2 \mathrm{BHL}$ Biodiversity Heritage Library}

Kesteven, H L. 1905. "Notes on Prosobranchiata. No. iv. - The ontogenetic stages represented by the gastropod protochonch." Proceedings of the Linnean Society of New South Wales 30, 325-335.

https://doi.org/10.5962/bhl.part.12905.

View This Item Online: $\underline{\text { https://www.biodiversitylibrary.org/item/30106 }}$

DOI: https://doi.org/10.5962/bhl.part.12905

Permalink: https://www.biodiversitylibrary.org/partpdf/12905

\section{Holding Institution}

MBLWHOI Library

\section{Sponsored by}

MBLWHOI Library

\section{Copyright \& Reuse}

Copyright Status: NOT_IN_COPYRIGHT

This document was created from content at the Biodiversity Heritage Library, the world's largest open access digital library for biodiversity literature and archives. Visit BHL at https://www.biodiversitylibrary.org. 